\title{
KEMAMPUAN PEMAHAMAN KONSEP MATEMATIS MAHASISWA PGSD PADA MATERI GEOMETRI DASAR
}

\author{
Putri Fitriasari \\ Universitas PGRI Palembang \\ putrifitriasari20@gmail.com
}

\begin{abstract}
ABSTRAK
Penelitian ini bertujuan untuk mendeskripsikan kemampuan pemahaman konsep matematis mahasiswa PGSD mengenai topik geometri dasar, serta mengidentifikasi kesulitan belajar mahasiswa pada topik geometri dasar. Penelitian ini menggunakan metode penelitian deskriptif. Subjek penelitian terdiri dari 40 orang mahasiswa tingkat pertama Program Studi Pendidikan Guru Sekolah Dasar Universitas PGRI Palembang. Data dalam penelitian ini dikumpulkan melalui tes tertulis tentang materi geometri dasar. Analisis data yang digunakan dalam penelitian ini adalah deskriptif kualitatif. Hasil analisis data diketahui bahwa rata-rata kemampuan pemahaman konsep matematis mahasiswa adalah 57,83 termasuk dalam kategori cukup. Dengan rincian 2 orang mahasiswa dengan kategori sangat baik, 14 orang mahasiswa dengan kategori baik, 15 orang mahasiswa dengan kategori cukup dan 9 orang mahasiswa dengan kategori kurang baik. Indikator kemampuan pemahaman matematis yang paling banyak muncul adalah kemampuan dalam mengklasifikasikan objek, sedangkan indikator yang paling sedikit adalah kemampuan dalam menjelaskan simetri lipat dan simetri putar pada bangun datar. Berdasarkan hasil penelitian dapat disimpulkan bahwa kemampuan pemahaman konsep matematis mahasiswa PGSD pada topik geometri dasar berada dalam kategori cukup.
\end{abstract}

Kata kunci : geometri, kesulitan belajar, pemahaman konsep matematis

\begin{abstract}
This study aims to describe students' understanding mathematical concepts of PGSD students regarding basic geometry topics, as well as identify student learning difficulties on basic geometry topics. This research uses descriptive research method. The research subjects consisted of 40 first-year students of the Primary School Teacher Education Study Program at the Palembang PGRI University. Data in this study were collected through written tests on basic geometry material. Analysis of the data used in this research is descriptive qualitative. The results of data analysis revealed that the average ability of understanding mathematical concepts of students was 57.83 included in the sufficient category. With the details of 2 students in very good categories, 14 students in good categories, 15 students in adequate categories and 9 students in poor categories. The most common indicator of mathematical understanding is the ability to classify objects, while the least indicator is the ability to explain folding symmetry and rotational symmetry on a flat figure. Based on the results of the study it can be concluded that the ability to understand mathematical concepts of PGSD students on basic geometry topics is in the sufficient category.
\end{abstract}

Keywords : geometry, learning difficulties, understanding mathematical concepts 


\section{PENDAHULUAN}

Geometri merupakan salah satu cabang ilmu matematika yang banyak digunakan dalam kehidupan sehari-hari. Walle (2001) menyatakan bahwa geometri merupakan hal yang esensial dalam kehidupan manusia, sejak zaman nenek moyang, geometri tidak hanya digunakan dalam matematika dan ilmu pengetahuan, namun geometri juga dapat ditemukan dalam bidang seni. Brumfiel (Roskawati, Ikhsan, dan Juandi, 2015) mengemukakan ada 4 (empat) hal yang menyebabkan geometri penting untuk dipelajari, yaitu: (1) geometri merupakan bidang ilmu yang di dalamnya terkandung keindahan logika dan ketelitian. Dengan kata lain geometri mengajarkan pembelajarnya untuk memiliki logika dan ketelitian, (2) geometri memiliki peranan dalam mendukung bidang ilmu yang lain, (3) geometri mengajarkan untuk memahami keindahan bentuk yang ada di sekitar kita, dan (4) geometri mengajarkan pembelajarnya untuk memiliki pemikiran ilmiah.

Napitupulu (Pierce, 2014) menjelaskan bahwa geometri merupakan pelajaran yang dapat membantu pembelajar untuk mengembangkan kemampuan pemecahan masalah, kemampuan menggeneralisasi dan menyimpulkan, serta kemampuan penalaran. The National Council of Teachers of Mathematics (NCTM) menambahkan bahwa geometri mempunyai peranan penting dalam kemampuan berpikir matematis. Pembelajaran geometri yang berlangsung di dalam kelas hendaknya dikaitkan dengan kehidupan nyata yang dapat dirasakan langsung oleh pembelajar. Oleh karena itu NCTM menempatkan pentingnya pemahaman pembelajar tentang geometri dimulai dari tingkat Sekolah Dasar (NCTM, 2000).

Pernyataan NCTM di atas menyiratkan bahwa untuk memberikan pengajaran geometri pada tingkat Sekolah Dasar tidak bisa dilakukan dengan sembarangan. Dengan kata lain, tenaga pengajar pada tingkat tersebut diharuskan untuk dapat memahami tentang pentingnya geometri dan bagaimana memberikan pembelajaran yang bermakna. Hal ini akan dapat terlaksana jika tenaga pengajar tersebut telah memahami dengan baik geometri itu sendiri.

Geometri dipelajari oleh mahasiswa tingkat pertama Program Studi Pendidikan Sekolah Dasar (PGSD). Mata kuliah ini tergabung dalam mata kuliah konsep dasar matematika untuk Sekolah Dasar. Berdasarkan kurikulum pendidikan tinggi mata kuliah ini bertujuan agar mahasiswa mampu memahami konsep-konsep dasar geometri.

Pembelajaran geometri, pada kenyataannya bukan hal yang mudah untuk dapat dipahami oleh pembelajar (Nuroniah, Suryadi, dan Sumiaty, 2016), termasuk juga bagi mahasiswa PGSD. Belajar geometri tidak hanya memerlukan keterampilan menghitung tetapi juga memerlukan kecakapan untuk berpikir dan beralasan secara matematis untuk menyelesaikan soal-soal baru dan mempelajari ide-ide baru yang akan dihadapi oleh peserta didik di masa yang akan datang (Walle, 2001).

Kesulitan mahasiswa dalam memahami konsep geometri ini dapat terjadi karena mahasiswa mengalami hambatan belajar (learning obstacles). Menurut Fuadiah, Suryadi, dan Turmudi (2016) hambatan belajar ini perlu diidentifikasi agar dapat ditemukan cara untuk mengatasinya. Selanjutnya, Depdiknas (Fuadiah, Suryadi, dan Turmudi, 2016) menyebutkan bahwa dalam memahami suatu topik matematika (termasuk geometri) ada beberapa kemungkinan yang dapat menyebabkan terjadinya hambatan dalam belajar yaitu: 1) pengetahuan prasyarat, 2) pemahaman konsep, 3) prosedur, 4) prinsip, dan 5) pemecahan masalah. 
Tulisan ini mengkaji tentang pemahaman konsep matematis mahasiswa PGSD tentang pokok bahasan geometri dasar yang terdiri dari titik, garis, sudut, bidang, segibanyak, simetri dan persamaan garis. Pemahaman berasal dari kata "paham" yang menurut Kamus Besar Bahasa Indonesia artinya adalah: pandai dan mengerti benar tentang suatu hal. Ruseffendi (2006) menjelaskan 3 macam pemahaman yaitu: pengubahan (translation), pemberian arti (interpretation), dan pembuatan ekstrapolasi. Pemahaman translasi adalah kemampuan untuk memahami suatu ide yang ditanyakan dalam cara lain dibandingkan dengan pernyataan asli yang dikenal sebelumnya, misalnya mampu mengubah soal kata-kata ke dalam simbol dan sebaliknya. Pemahaman interpretasi adalah kemampuan untuk memahami bahan atau ide yang direkam, diubah atau disusun dalam bentuk lain (seperti grafik, tabel, diagram). Pemahaman ekstrapolasi adalah keterampilan untuk meramalkan kekontinuan (kelanjutan) kecenderungan yang ada menurut suatu data.

Lebih lanjut, Anderson dan Krathwohl (2001) menyatakan bahwa mahasiswa dikatakan memahami sesuatu jika mereka mampu mengkonstruksi makna dari pesanpesan pengajaran seperti komunikasi lisan, tulisan, dan grafik. Pemahaman terdiri dari tujuh jenis, yaitu interpreting (menginterpretasikan), exemplifying (memberikan contoh), classifying (mengklasifikasikan), summarizing (meringkas), inferring (menyimpulkan), comparing (membandingkan), dan explaining (menjelaskan).

Pemahaman konsep matematis dalam pembelajaran geometri dapat diartikan sebagai kemampuan yang dimiliki oleh mahasiswa untuk mengerti dan memahami dengan benar konsep geometri termasuk di dalamnya dapat memberikan penjelasan tentang konsep berdasarkan pengetahuan yang telah dipelajarinya, dan mampu untuk menggunakan prosedur dan strategi penyelesaian terhadap suatu masalah atau tugas matematika.

Pemahaman konsep matematis menurut Depdiknas (Ningsih, 2016) diindikasikan sebagai kemampuan mahasiswa dalam: 1) menyatakan ulang sebuah konsep, 2) mengklasifikasi objek-objek menurut sifat-sifat tertentu (sesuai dengan konsepnya), 3) memberikan contoh dan non-contoh dari konsep, 4) menyajikan konsep dalam berbagai bentuk representasi matematis, 5) mengembangkan syarat perlu atau syarat cukup suatu konsep, 6) menggunakan, memanfaatkan, dan memilih prosedur atau operasi tertentu, dan 7) mengaplikasikan konsep atau algoritma ke pemecahan masalah.

Adapun tujuan penelitian ini adalah untuk mendeskripsikan kemampuan pemahaman konsep matematis mahasiswa PGSD tentang topik geometri dasar, dan mengidentifikasi kesulitan belajar mahasiswa dalam topik geometri dasar. Evaluasi kemampuan pemahaman konsep matematis dilakukan berdasarkan indikator Depdiknas namun dibatasi pada indikator berikut ini: 1) menyatakan ulang sebuah konsep, 2) memberikan contoh dan non-contoh, 3) menggunakan, memanfaatkan dan memilih prosedur, dan 4) mengaplikasikan konsep dalam pemecahan masalah.

\section{METODE}

Penelitian ini dilakukan pada bulan Oktober sampai bulan Desember 2019. Penelitian ini melibatkan 40 orang mahasiswa tingkat pertama Program Studi Pendidikan Sekolah Dasar (PGSD) Universitas PGRI Palembang tahun akademik 2019/2020. Penelitian ini menggunakan metode penelitian deskriptif, yang bertujuan untuk mendeskripsikan kemampuan pemahaman konsep matematis mahasiswa PGSD tentang topik geometri dasar. Instrumen dalam penelitian ini adalah berupa tes 
uraian yang telah divalidasi. Tes terdiri dari 4 soal uraian yang telah disusun berdasarkan indikator kemampuan pemahaman konsep matematis. Tes uraian yang diujikan kepada mahasiswa dapat dilihat pada Tabel 1.

Tabel 1. Instrumen tes kemampuan pemahaman konsep matematis

\begin{tabular}{|c|c|c|}
\hline $\begin{array}{c}\text { Nomor } \\
\text { soal }\end{array}$ & $\begin{array}{l}\text { Indikator } \\
\text { kemampuan } \\
\text { pemahaman } \\
\text { konsep } \\
\text { matematis }\end{array}$ & Soal \\
\hline 1 & $\begin{array}{l}\text { Menyatakan } \\
\text { ulang sebuah } \\
\text { konsep, yaitu } \\
\text { mahasiswa } \\
\text { mampu } \\
\text { menentukan } \\
\text { kedudukan titik, } \\
\text { garis, dan } \\
\text { bidang. }\end{array}$ & $\begin{array}{l}\text { Diketahui kubus } \mathrm{ABCD} \text {. EFGH, tentukan : } \\
\text { a. Titik yang berada diluar bidang } \mathrm{ADGF}\end{array}$ \\
\hline 2 & $\begin{array}{l}\text { Memberikan } \\
\text { contoh dan non- } \\
\text { contoh dari suatu } \\
\text { konsep, yaitu } \\
\text { mahasiswa } \\
\text { mampu } \\
\text { menentukan } \\
\text { contoh dan non- } \\
\text { contoh dari segi } \\
\text { banyak. }\end{array}$ & 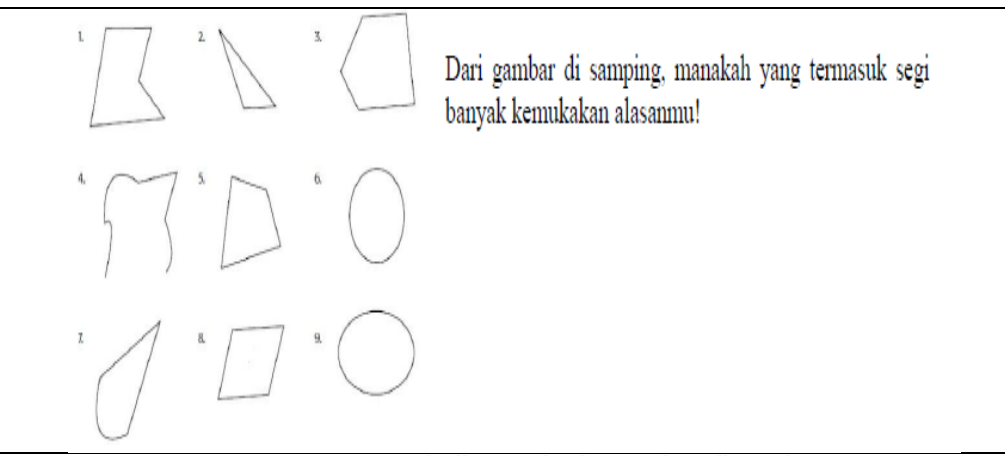 \\
\hline 3 & $\begin{array}{l}\text { Mengaplikasikan } \\
\text { konsep dalam } \\
\text { pemecahan } \\
\text { masalah, yaitu } \\
\text { mahasiswa } \\
\text { mampu } \\
\text { mengaplikasikan } \\
\text { dan menjelaskan } \\
\text { konsep simetri } \\
\text { lipat dan simetri } \\
\text { putar dari } \\
\text { segitiga samasisi } \\
\text { dan segiempat. } \\
\end{array}$ & $\begin{array}{l}\text { Perthatikan gambar bangun datar di samping! } \\
\text { Tentukan jumlah simetrin lipat dan simetri putarinya? Jelaskan! }\end{array}$ \\
\hline 4 & $\begin{array}{l}\text { Menggunakan, } \\
\text { memanfaatkan } \\
\text { dan memilih } \\
\text { prosedur, yaitu } \\
\text { mahasiswa } \\
\text { mampu } \\
\text { menentukan } \\
\text { hubungan dua } \\
\text { garis dari } \\
\text { gradien. }\end{array}$ & $\begin{array}{l}\text { Diketahui garis } g: 2 \mathrm{x}-3 \mathrm{y}=9 \text {, dan garis } l: y=-\frac{3}{2} x+5 \text {. Tentukan hubungan garis g dan } \\
\text { garis } l\end{array}$ \\
\hline
\end{tabular}


Data kemampuan pemahaman konsep matematis mahasiswa selanjutnya dianalisis secara deskriptif untuk mendapatkan gambaran yang jelas tentang pemahaman mahasiswa dalam pembelajaran geometri dasar. Nilai kemampuan pemahaman konsep matematis mahasiswa pada topik geometri dasar selanjutnya dikelompokkan sesuai dengan kriteria dari Arikunto (2010) yang dimodifikasi. Pengelompokan nilai disajikan pada Tabel 2.

Tabel 2. Kategori pemahaman konsep matematis

\begin{tabular}{cl}
\hline Nilai & Kategori \\
\hline $81-100$ & Sangat baik \\
$61-80$ & Baik \\
$41-60$ & Cukup \\
$21-40$ & Kurang baik \\
\hline
\end{tabular}

\section{HASIL DAN PEMBAHASAN}

Data hasil tes kemampuan pemahaman konsep matematis mahasiswa tingkat pertama PGSD Universitas PGRI Palembang tahun akademik 2019/2020 dapat dilihat pada Tabel 3 berikut ini:

Tabel 3. Distribusi kemampuan pemahaman konsep matematis mahasiswa

\begin{tabular}{ccl}
\hline Nilai akhir mahasiswa & Frekuensi & Kategori \\
\hline $81-100$ & 2 & Sangat baik \\
$61-80$ & 14 & Baik \\
$41-60$ & 15 & Cukup \\
$21-40$ & 9 & Kurang baik \\
\hline Jumlah & 40 & \\
\hline
\end{tabular}

Berdasarkan Tabel 3 diketahui bahwa frekuensi terbanyak kemampuan pemahaman konsep matematis mahasiswa berada pada kategori cukup, sedangkan nilai dengan kategori sangat baik hanya dimiliki oleh 2 orang mahasiswa atau sebesar $0,05 \%$. Hal ini menandakan bahwa materi geometri dasar belum sepenuhnya dikuasai oleh mahasiswa. Selanjutnya, untuk gambaran kemampuan pemahaman konsep matematis mahasiswa secara deskriptif kuantitatif dapat dilihat pada Tabel 4.

Tabel 4. Statistik deskriptif kemampuan pemahaman konsep matematis

\begin{tabular}{lc}
\hline \multicolumn{1}{c}{ Statistik } & Nilai \\
\hline Rata-rata & 57.83 \\
Median & 57.60 \\
Modus & 42.39 \\
Simpangan baku & 16.81 \\
Jangkauan & 72.83 \\
Minimum & 21.74 \\
Maximum & 94.57 \\
\hline Jumlah & 40 \\
\hline
\end{tabular}


Berdasarkan Tabel 4, diketahui bahwa kemampuan pemahaman konsep matematis mahasiswa memiliki rata-rata sebesar 57, 83 berada dalam kategori cukup. Nilai yang tertinggi adalah 94,57 dan nilai terendah yaitu 21,74. Hasil tes ini menunjukkan bahwa masih banyak mahasiswa yang memiliki nilai dengan kategori kurang baik. Dengan kata lain masih banyak mahasiswa yang mengalami kesulitan dalam memahami konsep geometri dasar. Ada sebanyak 24 orang atau $60 \%$ mahasiswa yang nilainya belum dalam kategori baik.

Untuk mengetahui letak kesulitan mahasiswa pada topik geometri dasar ini, analisis data kemudian dilanjutkan dengan melakukan perhitungan perbutir soal atau sesuai dengan indikator soal. Analisis hasil pekerjaan mahasiswa dalam menyelesaikan tes kemampuan pemahaman konsep matematis ditinjau dari 4 (empat) indikator yaitu sebagai berikut: 1) menyatakan ulang sebuah konsep, 2) memberikan contoh dan non-contoh, 3) menggunakan, memanfaatkan dan memilih prosedur, dan 4) mengaplikasikan konsep dalam pemecahan masalah. Hasil pekerjaan mahasiswa pada setiap indikator dapat dilihat pada Tabel 5.

Tabel 5. Nilai kemampuan pemahaman konsep matematis untuk setiap indikator

\begin{tabular}{clcc}
\hline No. & $\begin{array}{l}\text { Indikator kemampuan pemahaman konsep } \\
\text { matematika }\end{array}$ & Nilai & Kategori \\
\hline 1. & $\begin{array}{l}\text { Kemampuan menyatakan ulang sebuah } \\
\text { konsep }\end{array}$ & 61,13 & Baik \\
\hline 2. & $\begin{array}{l}\text { Kemampuan memberi contoh dan bukan } \\
\text { contoh }\end{array}$ & 66,38 & Baik \\
\hline 3. & $\begin{array}{l}\text { Kemampuan menggunakan, memanfaatkan } \\
\text { dan memilih prosedur tertentu }\end{array}$ & 62,35 & Baik \\
\hline 4. & $\begin{array}{l}\text { Kemampuan mengaplikasikan } \\
\text { konsep/algoritma ke pemecahan masalah }\end{array}$ & 52,50 & Cukup \\
\hline
\end{tabular}

Berdasarkan Tabel 5, diketahui bahwa indikator yang tertinggi ada pada indikator kemampuan mahasiswa dalam memberikan contoh dan non contoh dari konsep segibanyak. Sedangkan indikator yang paling sedikit muncul yaitu kemampuan mahasiswa dalam mengaplikasikan konsep/algoritma ke pemecahan masalah. Penjelasan lengkap tentang kemampuan pemahaman konsep matematis mahasiswa untuk setiap indikator dijelaskan sebagai berikut:

1) Kemampuan menyatakan ulang sebuah konsep

Kemampuan ini diindikasikan dengan kemampuan mahasiswa dalam menuliskan kembali konsep titik, garis dan bidang. Rata-rata nilai mahasiswa untuk kemampuan ini adalah sebesar 61,13 . Hasil analisis data menunjukkan bahwa ada mahasiswa yang masih keliru dalam menuliskan kedudukan titik terhadap bidang, dan kedudukan garis terhadap bidang. Dalam menuliskan titik dan garis banyak mahasiswa yang membuatnya tidak sesuai dengan konsep. Mahasiswa salah dalam menentukan garis yang sejajar dengan garis DE pada kubus ABCD.EFGH. Berdasarkan gambar soal diketahui bahwa garis yang sejajar dengan DE adalah garis CF. Selain itu mahasiswa juga salah dalam menentukan dua garis yang berpotongan dan dua bidang yang sejajar. Hasil pekerjaan mahasiswa untuk indikator ini dapat dilihat pada Gambar 1. Kurangnya kemampuan mahasiswa dalam memahami konsep geometri ini juga dinyatakan oleh Roskawati, Ikhsan, dan Juandi (2015). 


\begin{tabular}{|c|}
\hline b. Garis yang sejajar \\
\hline$D H, D A, D B, D C, D F$ \\
\hline c. Garis yang berpotongan \\
\hline d. Bidang yang sesajar BCGF \\
\hline FEAB $=$ \\
\hline
\end{tabular}

Gambar 1. Contoh jawaban mahasiswa yang keliru dalam menentukan kedudukan garis dan bidang

2) Kemampuan memberikan contoh dan bukan contoh

Deskriptor pada indikator ini adalah mahasiswa mampu menentukan contoh dan bukan contoh dari konsep segibanyak. Mahasiswa dituntut untuk dapat menentukan bangun datar segibanyak dari 8 jenis bangun datar yang disajikan. Berdasarkan analisis data, diketahui bahwa rata-rata nilai indikator ini merupakan rata-rata tertinggi yaitu 66,38. Hal ini menunjukkan bahwa lebih dari 50\% mahasiswa mempunyai kemampuan yang baik dalam menentukan contoh dan bukan contoh segibanyak. Meskipun demikian, masih terdapat mahasiswa yang melakukan kesalahan dalam menentukan segibanyak. Kesalahan tersebut antara lain adalah segitiga (pada soal gambar 2) bukan merupakan contoh dari segibanyak, dan lingkaran (pada soal gambar 6) merupakan suatu contoh dari segibanyak. Contoh jawaban mahasiswa dapat dilihat pada Gambar 2.

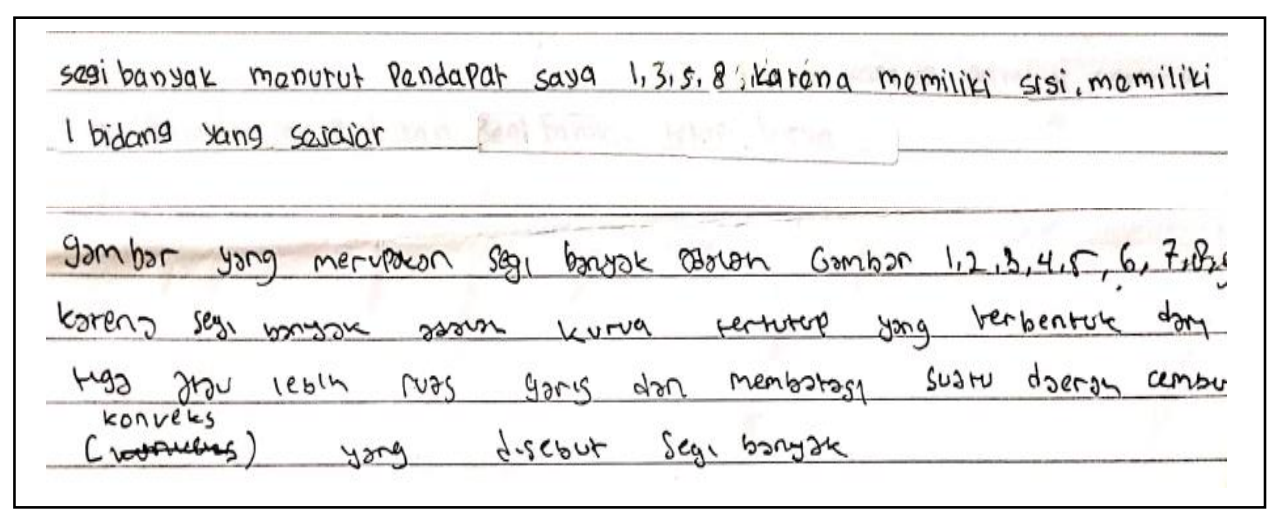

Gambar 2. Contoh jawaban mahasiswa yang keliru dalam menentukan contoh segibanyak

Kesalahan mahasiswa dalam menentukan contoh segibanyak ini disebabkan karena mahasiswa belum menguasai konsep dan definisi dari segibanyak. Definisi dari sebuah objek merupakan hal yang penting dalam pembelajaran geometri. Pernyataan ini disebutkan oleh Özerem (2012) yaitu kemampuan dalam menentukan dan mendefinisikan suatu objek merupakan indikator kesuksesan dalam pembelajaran geometri. 
3) Kemampuan menggunakan, memanfaatkan dan memilih prosedur tertentu

Deskriptor dari kemampuan ini adalah mahasiswa mampu menentukan gradien dari sebuah garis, dan menentukan kedudukan dari garis tersebut berdasarkan gradien yang diketahui. Dalam hal ini, mahasiswa dituntut untuk dapat menerapkan konsep dari gradien untuk dua buah garis yang saling tegak lurus. Rata-rata nilai mahasiswa untuk indikator ini adalah sebesar 62,35. Nilai ini menunjukkan bahwa rata-rata mahasiswa dapat menggunakan prosedur untuk menentukan hubungan dua garis dengan baik.

Namun, meskipun demikian masih juga terdapat mahasiswa yang melakukan kesalahan dalam menentukan persamaan garis. Berdasarkan hasil analisis data diketahui bahwa kesalahan mahasiswa pada indikator ini adalah sebagai berikut: mahasiswa salah dalam melakukan operasi aljabar untuk menentukan persamaan garis sehingga gradien yang diperoleh juga salah, mahasiswa keliru dalam memahami maksud soal, mahasiswa tidak dapat menentukan hubungan dua garis berdasarkan gradiennya. Kesalahan tersebut sejalan dengan hasil kajian terdahulu yang disampaikan oleh Sumarsih (2016). Hasil pekerjaan mahasiswa untuk indikator ini dapat dilihat pada Gambar 3.

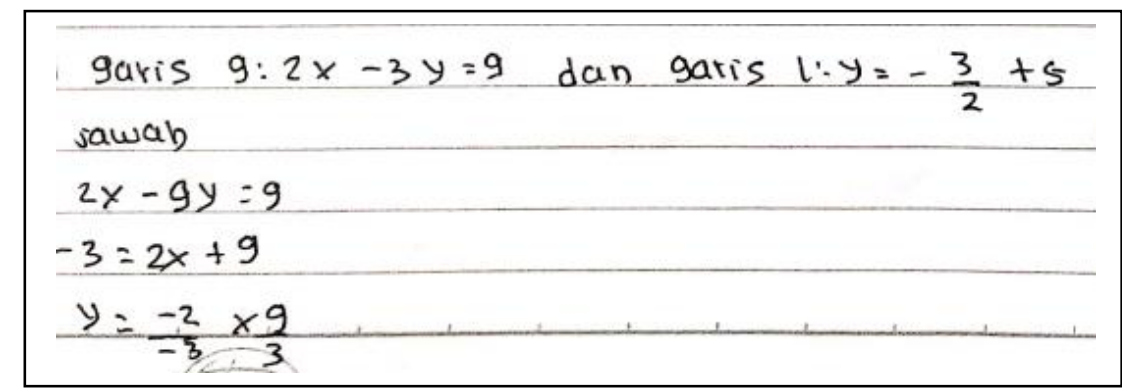

Gambar 3. Contoh jawaban mahasiswa yang keliru dalam menentukan gradien

4) Kemampuan mengaplikasikan konsep/algoritma ke pemecahan masalah

Deskriptor dari indikator ini adalah kemampuan mahasiswa dalam mengaplikasikan konsep simetri untuk menentukan banyaknya simetri lipat dan simetri putar dari 6 macam bangun datar yang disajikan. Berdasarkan hasil analisis data diketahui bahwa nilai rata-rata untuk kemampuan ini adalah sebesar 52,50 termasuk dalam kategori cukup. Kemampuan ini menuntut mahasiwa untuk mampu memahami konsep simetri lipat dan simetri putar, dan menerapkannya dalam menentukan banyaknya simetri lipat dan simetri putar dari 6 macam bangun datar. Selain itu, kemampuan ini juga mengharuskan mahasiswa untuk dapat menjelaskan konsep yang dipahaminya dalam menyelesaikan permasalahan. Penjelasan yang dituliskan oleh mahasiswa menunjukkan bahwa ia telah memahami konsep simetri dengan baik.

Hasil analisis data menunjukkan bahwa banyak mahasiswa yang tidak dapat memenuhi kemampuan ini, khususnya untuk simetri putar. Kesalahan mahasiswa pada indikator ini adalah sebagian besar mahasiswa tidak memberikan penjelasan dari jawaban yang telah dituliskan. Selain itu terkait simetri putar, kesalahan yang umum dilakukan mahasiswa adalah tidak dapat memahami besaran sudut dalam melakukan simetri putar, dan tidak dapat menentukan sumbu simetri putar dengan benar. Kelemahan mahasiswa dalam memahami konsep simetri ini sejalan dengan kajian terdahulu yang disampaikan oleh Kaplan dan Öztürk (2014). 


\section{SIMPULAN}

Berdasarkan hasil penelitian dapat disimpulkan bahwa kemampuan pemahaman konsep matematis mahasiswa PGSD pada topik geometri dasar secara keseluruhan berada dalam kategori cukup. Mahasiswa yang memiliki kemampuan pemahaman konsep sangat baik terdiri dari 2 orang, 14 orang mahasiswa memiliki kemampuan pemahaman konsep matematis dalam kategori baik, 15 orang mahasiswa dalam kategori cukup, dan 9 orang mahasiswa dalam kategori kurang baik. Indikator yang paling banyak muncul adalah kemampuan mahasiswa dalam mmenentukan contoh dan bukan contoh dari konsep segibanyak, sedangkan indikator yang paling sedikit muncul adalah kemampuan mahasiswa dalam mengaplikasikan konsep dalam pemecahan masalah. Mahasiswa masih mengalami kesulitan dalam menentukan dan menjelaskan simetri putar dari beberapa bangun datar, khususnya segitiga.

Saran yang dapat disampaikan terkait dengan hasil penelitian ini adalah perlu dilakukan upaya lanjutan untuk meningkatkan kemampuan pemahaman konsep matematis mahasiswa PGSD pada topik geometri dasar, agar nantinya setelah menjadi guru, mereka tidak salah mengajarkan materi tersebut.

\section{DAFTAR PUSTAKA}

Anderson, L. W., and Krathwohl, D. 2001. A Taxonomy for Learning Teaching and Assessing. Newyork: Longman.

Arikunto, S. 2010. Prosedur Penelitian: Suatu Pendekatan Praktek. Jakarta: Rineka Cipta.

Fuadiah, N. F., Suryadi, D., dan Turmudi. 2016. Identifikasi Kesulitan Siswa Sekolah Menengah dalam Memahami Bilangan Negatif. dalam D. Suryadi, E. Mulyana, T. Suratno, D. Dewi, dan S. Maudy, Monograf Didactical Desain Research (hal. 121). Bandung: Rizqi Press.

Kaplan, A., and Öztürk, M. 2014. Analysis of 2nd-8th Grade Students' Thinking Approaches Toward Understand the Concept of Symmetry. Elementary Education Online, Vol. 13(4) : 1502-1515.

NCTM. 2000. Principles and Standards for School Mathematics. United States of America : The National Council of Teachers of Mathematics, Inc.

Ningsih, Y. L. 2016. Kemampuan Pemahaman Konsep Matematika Mahasiswa Melalui Penerapan Lembar Aktivitas Mahasiswa (LAM) Berbasis Teori Apos Pada Materi Turunan. Edumatica, Vol. 6(1) : 1-8.

Nuroniah, S., Suryadi, D., dan Sumiaty, E. 2016. Disain Didaktis Konsep Luas Daerah Segitiga dan Segiempat Berdasarkan Analisis Learning Obstacle dan Learning Trajectory. dalam D. Suryadi, E. Mulyana, T. Suratno, D. K. Dewi, dan S. Maudy, Monograf Didactical Design Research (hal. 48). Bandung: Rizqi Press.

Özerem, A. 2012. Misconceptions In Geometry And Suggested Solutions For Seventh Grade Students. Procedia - Social and Behavioral Sciences, Vol. 55 : 720-729.

Pierce, B. G. 2014. Examination of High School Students' Understanding of Geometry. [Online]. Tersedia: https://aquila.usm.edu/masters_theses/40. [20 Desember 2019]. 
Roskawati, Ikhsan, M., dan Juandi, D. 2015. Analisis Penguasaan Siswa Sekolah Menengah Atas pada Materi Geometri. Jurnal Didaktik Matematika, Vol. 2(1) : 64-70.

Ruseffendi, E. 2006. Pengantar kepada Membantu Guru Mengembangkan Kompetensinya dalam Pengajaran Matematika Untuk Meningkatkan CBSA. Bandung: Tarsito.

Sumarsih. 2016. Analisis Kesulitan Siswa SMP dalam Mempelajari Persamaan Garis Lurus dan Alternatif Pemecahannya. Prosiding Seminar Nasional Matematika dan Pendidikan Matematika FKIP UNS, Solo, Rabu 16 November 2016.

Walle, J. V. 2001. Elementary and Middle School Mathematics: Teaching Developmentally. Boston, MA: Allyn and Bacon. 